\title{
Chapter 6 \\ Article 7: The Right to a Name, Nationality, and to Know and Be Cared for by Parents
}

\author{
Adem Arkadas-Thibert and Gerison Lansdown
}

1. The child shall be registered immediately after birth and shall have the right from birth to a name, the right to acquire a nationality and, as far as possible, the right to know and be cared for by his or her parents.

2. States Parties shall ensure the implementation of these rights in accordance with their national law and their obligations under the relevant international instruments in this field, in particular where the child would otherwise be stateless.

\section{What Did Children Say?}

'Government should provide birth certificates and medical reports to let the children know where they came from.' (Asia-Pacific)

'Government should aware every parent on the process and importance of childbirth registration.' (Asia-Pacific)

'Government should simplify the process of registration.' (Asia-Pacific)

'Hospitals should not release newborns before ensuring that they are registered.' (Eastern Europe)

\footnotetext{
A. Arkadas-Thibert $(\bowtie)$

Marseille, France

G. Lansdown

Carleton University, Ottawa, ON, Canada 


\section{Overview}

The rights to a name, birth registration, and nationality are well-established rights in international and national laws. All non-discrimination clauses of all international and regional human rights treaties include birth as a prohibited ground for discrimination. The Convention built on these treaties and introduced a new component asserting the right of the child to know and be cared for by their parents, in recognition that parental care is as important for the child's psychological stability and development as a name and nationality (Office of the United Nations High Commissioner for Human Rights and Rädda Barnen (Society: Sweden), 2007, pp. 379-80; Scruton, 2007, p. 92). Although Article 7 does not explicitly grant citizenship, international law does not make a distinction between citizenship and nationality. Rather, it regards the former as completely determined by the latter (Scruton, 2007).

The wording of Article 7 creates a strong presumption in support of the child's right to nationality and citizenship but not an absolute guarantee against statelessness (Tobin \& Seow, 2019, p. 241). Proposals during the drafting of Article 7 were put forward to introduce a right to be granted nationality based on where the child was born. However, this was rejected in favour of a provision that enabled a child to acquire nationality either through the nationality of their parents or their place of birth, subject to the national law of the country (Office of the United Nations High Commissioner for Human Rights and Rädda Barnen (Society: Sweden), 2007, para. 103).

Overall, Article 7 aims to facilitate recognition of the legal personality of the child as an independent human being having agency to exercise their rights everywhere from birth, through the right to a name, through provision of full citizenship rights, through nationality, and through preventing statelessness (Hodgkin et al., 2007, pp. 97-109). In addition, in recognition of the importance of the child's parentage to their identity and optimum development, the article introduces an additional element as foundational to the best interest of the child: the right of the child to know their parents and to be cared for by their parents.

\section{General Principles}

Article 2 Birth is included as one of the prohibited grounds of discrimination in Article 2 of the Convention. Accordingly, all children must be registered without delay at birth and granted a nationality without discrimination. The Committee has highlighted concerns ${ }^{1}$ relating to many groups of children at risk of discrimination with regard to birth registration and/or nationality including refugees, children of

\footnotetext{
${ }^{1}$ For example, see Concluding observations: Estonia (UN Committee on the Rights of the Child, 2003) and Concluding observations: Jordan (UN Committee on the Rights of the Child, 1994a).
} 
unmarried couples, children who were born after their parents divorced, children born out of surrogacy agreements, adopted children, children born during flight from a conflict/refugee children, children of migrant parents, children of nomadic tribes, children of indigenous groups, and children of ethnic minorities (UN Office of the High Commissioner for Human Rights (OHCHR), 2010, paras. 57-61).

Article 3 In certain countries, the right of an adopted child or a child born through assisted reproductive technologies to know their birth parents is overridden in favour of the right of parents to privacy and confidentiality. Although such approaches are sometimes defended as promoting the best interests of the child (Odievre v. France, 2003), the Committee has argued that Article 7 creates strong presumption in favour of full disclosure of a child's genetic parentage. In other words, the child's best interests are served by access to information relating to their birth and birth parents (UN Committee on the Rights of the Child, 2004, para. 23, 2005a, paras. 28-29, 2005 b, para. 38 et al., 2009, para. 16). In addition, the right to be cared for by one's parents is qualified by the phrase 'as far as possible.' The imperative to secure the best interests of the child would be a potential factor in determining whether it was possible to for a child to be cared for by their parents.

Article 6 Many services that are imperative for a child's development, as well as lifesaving services provided by public administration, require birth registration of the child or introduce limitations on nationality grounds. Therefore, the right to a name and nationality can be understood as an enabling right and indispensable for life and development of the child. However, lack of registration should not be used as an excuse to discriminate against those children whose birth registration is marred by inadequate or latent discriminatory laws and policies.

Article 12 Children's civil and political participation as citizens of a given country is dependent on their registration as a national in that country. Any restriction of birth registration hampers the child from exercising and enjoying their rights to participation. For example, restricting right to peaceful assembly only to those who are citizens infringes the right to fully participate in public life.

\section{Articles Related or Linked to Article 7}

Article 8, preservation of identity, including nationality, name, and family relations, relies on the name and nationality of the child being afforded from the birth of the child

Article 9, separation from parents constitutes a greater risk for children lacking birth registration

Article 10, family reunification is highly dependent on children having access to documentation relating to their birth registration

Article 18, parents have joint responsibility for their children and should be named on the birth certificate wherever possible 
Article 20, children deprived of their family environment are entitled to access their original birth registration documents in order to provide them with knowledge of their birth family and to provide continuity

Article 21, adoption and inter-country adoption can result in children being provided with a new name and parents, but children should have access to their original birth registration wherever possible

Article 22, asylum seeking and refugee children are at greater risk of loss of identity and will often require birth documentation in order to apply for refugee status

Article 30, children of minorities or indigenous peoples will often be at risk of discrimination and loss of status if they are unable to provide birth registration documentation

Article 35, prevention of sale, trafficking and abduction necessitates that children have access to their birth registration documents.

\section{Relevant Instruments}

The UN Universal Declaration of Human Rights (1948), Article 15, provides for the right to a nationality.

The International Covenant on Civil and Political Rights (1966), Article 24, provides for rights to birth registration and to a nationality.

Some other human rights treaties also cover these rights:

- International Convention on the Elimination of all forms of Racial Discrimination (1966), Article 5

- UN Convention on the Elimination of All Forms of Discrimination against Women (1979), Article 9

- International Convention on the Protection of the Rights of All Migrant Workers and Members of Their Families (1990), Article 29

- UN Convention on the Rights of Persons with Disabilities (2006), Article 18

- UN International Convention for the Protection of All Persons from Enforced Disappearance (2007), Article 25

- American Convention on Human Rights 'Pact of San Jose, Costa Rica' (B-32) (1978), Article 20

- African Charter on the Rights and Welfare of the Child (1990), Article 6

- Protocol to the African Charter on Human and Peoples' Rights on the Rights of Women in Africa (2003), Article 6. 


\section{Attributes}

\section{Attribute One: Free, Compulsory, and Accessible Birth Registration Immediately After Birth of All Children}

A central tenet of Article 7 is free, compulsory, and accessible birth registration, immediately after the child's birth. Information on implementation of this right constitutes part of the common core document that all treaty bodies require from States Parties in their constructive dialogues with them (United Nations, 2009). As the Human Rights Committee pointed out in their General Comment no. 17 on the Rights of the Child (ICCPR 2011), birth registration is an enabling right, and must therefore be free, compulsory, and accessible for all, including hard to reach populations, through mobile units, public information campaigns, and as part of pre-natal and post-natal health care services (United Nations, 2006, p. 183).

Birth registration is a vital passport to accessing health services, social security, and education. It can be facilitated using digital and mobile birth registration systems. There also need to be opportunities for non-registered children to have their birth registration easily completed later through health care, educational, and social services (United Nations, 2006, p. 183).

\section{Attribute Two: Acquiring a Name, Nationality, and Prevention of Statelessness of a Child}

The right to a name from birth is widely recognised in international law and affords the child both legal status and an identity and sense of self. Although the naming of a child at birth is, inevitably, a right exercised by the parents on behalf of the child, the Committee makes clear that there are limits to the scope of parental discretion. In line with Article 12, a child of sufficient age and maturity has the right to change, or refuse to change, their name. ${ }^{2}$ Such a circumstance might arise, for example, in the context of parental divorce, separation, or marriage, or adoption.

Closely linked to the right to a name is the right to acquisition of nationality, a provision which, as with birth registration, States Parties are required to provide information on for all treaty bodies. It is an enabling right and included in non-discrimination clauses, as a necessary pathway to non-discriminatory service provision for children (United Nations, 2009). The Committee has emphasised that States Parties must adopt all possible measures to ensure that every child has a nationality from birth. This requirement effectively imposes an obligation on States Parties to ensure that no child is left stateless (UN Committee on the Protection of the

\footnotetext{
${ }^{2}$ See, for example, Concluding observations for Niue Islands (UN Committee on the Rights of the Child, 2013a, paras. 30-31) and Federal republic of Yugoslavia, (Serbia and Montenegro) (UN Committee on the Rights of the Child, 1996, para. 31).
} 
Rights of All Migrant Workers and Members of Their Families and UN Committee on the Rights of the Child, 2017, paras. 20-26). To this end, it has recommended to States Parties that they collect data on stateless children, collaborate with relevant international agencies, legislate to protect against arbitrary deprivation of nationality, and become party to relevant international instruments that protect against statelessness (Tobin \& Seow, 2019, p. 256).

In accordance with Article 2, States Parties should not discriminate in respect of acquisition of nationality, on the basis of the nationality of a child being different to the country in which they live, or because of the lack of nationality (UN Committee on the Protection of the Rights of All Migrant Workers and Members of Their Families and UN Committee on the Rights of the Child, 2017, para. 25). States Parties must provide options for children to acquire citizenship without discrimination within their jurisdiction (UN Committee on the Rights of the Child, 2005c, paras. 11,12 ). Consideration should also be given to both parents equally being able to pass their nationality to their children, in accordance with Article 9 of the Convention on the Elimination of All Forms of Discrimination against Women.

\section{Attribute Three: Knowing and Being Cared for by Their Parents}

All children have a right to know their origins and their parents. The right of the child to know and be cared for by their parents, as far as possible, provides a baseline for interpretation of other rights relating to the child's right to family life, including the presumption against separation from parents (Article 9), family reunification (Article 10), responsibilities for both parents to care for their children (Articles 18 and 27), and the rights of children in alternative care and to adoption (Articles 20 and 21) (Tobin \& Seow, 2019, p. 239). The Convention does not define parents, but the Committee has stressed the need to understand the term in its broadest sense to include 'biological, adoptive, or foster parents or members of the extended family or community as provided for by local custom' (UN Committee on the Rights of the Child, 2013b, para. 59). Furthermore, taken in conjunction with Article 8, the right to preserve identity, the term can also be understood to include knowing the identity of any person with whom they have a gestational or biological link, for example, as a result of assisted reproductive technologies or surrogacy (Gaskin v. The United Kingdom, 1989, para. 39).

The qualification that this right must be exercised 'as far as possible' allows that in some circumstances it may not be possible for the child to know their parents: the parentage may not be known, disclosure may run counter to the child's best interests, or it may lead to a conflict of other interests such as the privacy of a biological parent. 
However, the presumption is very strongly in favour of the child's right to know. ${ }^{3}$ In cases where the child is placed in protective custody of another family in the form of foster care, adoption, or institutional care, the child should be provided with option to know their parents and origins (UN Committee on the Rights of the Child, 2004, para. 23, 2005a, paras. 28, 29, 2005b, para. 38 et al.). This option should consider the best interests of the child, providing the child with enough information to make an informed decision.

\section{References}

Gaskin v. The United Kingdom. (1989). European Court of Human Rights. Accessed October 22, 2020, from http://hudoc.echr.coe.int/eng? $i=001-57491$.

Hodgkin, R., Newell, P., \& UNICEF. (2007). Implementation handbook for the Convention on the Rights of the Child (3rd ed.). UNICEF. Accessed September 21, 2020, from https:// digitallibrary.un.org/record/620060? $\mathrm{ln}=\mathrm{en}$.

Odievre v. France. (2003). European Court of Human Rights. Accessed October 13, 2020, from http://hudoc.echr.coe.int/eng?i=001-60935.

Office of the United Nations High Commissioner for Human Rights \& Rädda Barnen (Society: Sweden). (2007). Legislative history of the Convention on the Rights of the Child. United Nations. https://digitallibrary.un.org/record/602462? $\mathrm{ln}=\mathrm{en}$

Scruton, R. (2007). The Palgrave Macmillan dictionary of political thought (3rd ed.). Palgrave Macmillan. https://doi.org/10.1057/9780230625099

Tobin, J., \& Seow, F. S. (2019). Article 7: The rights to birth registration, a name, nationality and to know and be cared for by parents. In J. Tobin (Ed.), The UN Convention on the Rights of the Child: A commentary (pp. 237-280). Oxford University Press.

UN Committee on the Protection of the Rights of All Migrant Workers and Members of Their Families \& UN Committee on the Rights of the Child. (2017, November 16). Joint general comment no. 23 (2017) on State obligations regarding the human rights of children in the context of international migration in countries of origin, transit, destination and return, $C M W / C / G C / 4, C R C / C / G C / 23$. Accessed October 12, 2020, from https://digitallibrary.un.org/ record $/ 1323015 ? \ln =$ en.

UN Committee on the Rights of the Child. (1994a, April 25). Concluding observations: Jordan, CRC/C/15/Add.21. Accessed October 12, 2020, from https://digitallibrary.un.org/record/ $161440 ? \ln =\mathrm{en}$.

UN Committee on the Rights of the Child. (1994b, April 25). Concluding observations: Norway, CRC/C/15/Add.23. Accessed October 23, 2020, from https://digitallibrary.un.org/record/ $197744 ? \ln =$ en.

UN Committee on the Rights of the Child. (1995, February 15). Concluding observations: Denmark, CRC/C/15/Add.33. Accessed October 23, 2020, from https://digitallibrary.un.org/ record/198497? In $=$ en.

UN Committee on the Rights of the Child. (1996, February 13). Concluding observations: Yugoslavia (Serbia and Montenegro), CRC/C/15/Add.49. Accessed October 11, 2020, from https://digitallibrary.un.org/record/210143? $\mathrm{ln}=\mathrm{en}$.

\footnotetext{
${ }^{3}$ See, for example, concluding observations of the Committee on Norway (1994b, para. 10), Denmark (1995, para. 11), Morocco (2014, para. 33), Luxembourg (2005a, paras. 28, 29), France (2004, para. 23), and Armenia (2005b, para. 38 et al.) CRC/C/15/Add.225, para. 38 et al.
} 
UN Committee on the Rights of the Child. (2003, March 17). Concluding observations: Estonia, CRC/C/15/Add.196. Accessed October 12, 2020, from https://digitallibrary.un.org/record/ $497792 ? \ln =\mathrm{en}$.

UN Committee on the Rights of the Child. (2004, June 30). Concluding observations: France, CRC/C/15/Add.240. Accessed October 12, 2020, from https://digitallibrary.un.org/record/ $536574 ? \ln =$ en.

UN Committee on the Rights of the Child. (2005a, March 31). Concluding observations: Luxembourg, CRC/C/15/Add.250. Accessed October 11, 2020, from https://digitallibrary.un.org/ record $/ 557392 ? \mathrm{ln}=$ en.

UN Committee on the Rights of the Child. (2005b, October 12). Concluding observations: Algeria, CRC/C/15/Add.269. Accessed October 24, 2020, from https://digitallibrary.un.org/record/ $570473 ? \mathrm{ln}=\mathrm{en}$.

UN Committee on the Rights of the Child. (2005c, September 1). General comment no. 6 (2005) treatment of unaccompanied and separated children outside their country of origin, $C R C / G C /$ 2005/6. Accessed October 12, 2020, from https://digitallibrary.un.org/record/566055? $\mathrm{ln}=\mathrm{en}$.

UN Committee on the Rights of the Child. (2009, February 12). General comment no. 11 (2009), Indigenous children and their rights under the Convention, $C R C / C / G C / 11$. Accessed October 24, 2020, from https://digitallibrary.un.org/record/648790? $1 \mathrm{n}=\mathrm{en}$.

UN Committee on the Rights of the Child. (2013a, June 26). Concluding observations: Niue, CRC/C/NIU/CO/1. Accessed October 11, 2020, from https://digitallibrary.un.org/record/ $751626 ? \mathrm{ln}=\mathrm{en}$.

UN Committee on the Rights of the Child. (2013b, May 29). General comment no. 14 (2013) on the right of the child to have his or her best interests taken as a primary consideration (art. 3, para. 1), $C R C / C / G C / 14$. Accessed October 12, 2020, from https://digitallibrary.un.org/record/ $778523 ? \ln =\mathrm{en}$.

UN Committee on the Rights of the Child. (2014, October 14). Concluding observations: Morocco, CRC/C/MAR/CO/3-4. Accessed October 23, 2020, from https://digitallibrary.un.org/record/ $793887 ? \mathrm{ln}=\mathrm{en}$.

United Nations. (2006). Compilation of general comments and general recommendations adopted by human rights treaty bodies, HRI/GEN/1/Rev. 8. UN. Accessed April 19, 2020, from http:// digitallibrary.un.org/record/576098.

United Nations. (2009). Compilation of guidelines on the form and content of reports to be submitted by States parties to the international human rights treaties, HRI/GEN/2/Rev. 6. UN. Accessed October 13, 2020, from https://digitallibrary.un.org/record/658873? ln=en.

UN Office of the High Commissioner for Human Rights (OHCHR). (2010). Report of the Office of the United Nations High Commissioner for Human Rights on challenges and best practices in the implementation of the international framework for the protection of the rights of the child in the context of migration, 2010, A/HRC/15/29. https://documents-dds-ny.un.org/doc/UNDOC/ GEN/G10/151/41/pdf/G1015141.pdf?OpenElement

Open Access This chapter is licensed under the terms of the Creative Commons Attribution 4.0 International License (http://creativecommons.org/licenses/by/4.0/), which permits use, sharing, adaptation, distribution and reproduction in any medium or format, as long as you give appropriate credit to the original author(s) and the source, provide a link to the Creative Commons license and indicate if changes were made.

The images or other third party material in this chapter are included in the chapter's Creative Commons license, unless indicated otherwise in a credit line to the material. If material is not included in the chapter's Creative Commons license and your intended use is not permitted by statutory regulation or exceeds the permitted use, you will need to obtain permission directly from the copyright holder.

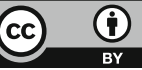

